\title{
PENGARUH KEPEMIMPINAN TRANSFORMASIONAL TERHADAP KINERJA KARYAWAN DENGANEFIKASI DIRI SEBAGAI VARIABEL MEDIASI
}

\author{
Ida Bagus Agung Aditya Wijaya ${ }^{1}$ \\ I Gusti Ayu Manuati Dewi \\ ${ }^{1,2}$ Jurusan Manajemen Fakultas Ekonomi dan Bisnis Universitas Udayana (Unud), \\ Bali, Indonesia \\ email: gusagunggg@gmail.com
}

\begin{abstract}
ABSTRAK
Fenomena terkait penurunan kinerja karyawan di Hotel Samabe Bali Suite and Villas Nusa Dua, Badung, menuntut perusahaan untuk senantiasa mengoptimalkan kinerja para karyawannya dengan memperhatikan kepemimpinan transformasional yang dimediasi dengan efikasi diri. Penelitian ini bertujuan untuk menjelaskan pengaruh kepemimpinan transformasional terhadap efikasi diri, menjelaskan pengaruh kepemimpinan transformasional dan efikasi diriterhadap kinerja karyawan, sertamenjelaskan peran efikasi diri memediasi pengaruh kepemimpinan transformasional terhadap kinerjakaryawan.Sampel penelitian ditentukan dengan metode proportionate stratified random sampling sebanyak 108 orang karyawan. Pengumpulan data dilakukan dengan metode wawancara dan penyebaran kuesioner. Pengujian hipotesis dalam penelitian ini menggunakan analisis jalur (path analysis). Berdasarkan hasil pembahasan, maka didapat simpulan dari hasil penelitian adalah:kepemimpinan transformasional berpengaruh positif dan signifikan terhadap efikasi diri, kepemimpinan transformasional berpengaruh positif dan signifikan terhadap kinerja karyawan, efikasi diri berpengaruh positif dan signifikan terhadap kinerja karyawan, dan efikasi diri berperan mediasi pengaruh kepemimpinan transformasional terhadap kinerja karyawan di Hotel Samabe Bali Suite and Villas Nusa Dua, Badung.
\end{abstract}

Kata kunci: Kepemimpinan Transformasional, Kinerja Karyawan, efikasi diri.

\begin{abstract}
The phenomenon related to the decline in employee performance at the Samabe Hotel Bali Suites and Villas Nusa Dua, Badung, requires the company to always optimize the performance of its employees by paying attention to transformational leadership that is mediated by self-efficacy. This study aims to explain the effect of transformational leadership on self-efficacy, explain the effect of transformational leadership and selfefficacy on employee performance, and explain the role of self-efficacy mediating the effect of transformational leadership on employee performance. The research sample was determined by the proportionate stratified random sampling method of 108 employees. Data collection was carried out by interview and questionnaire method. Testing the hypothesis in this study using path analysis. Based on the results of the discussion, the conclusions obtained from the results of the study are: transformational leadership has a positive and significant effect on self-efficacy, transformational leadership has a positive and significant effect on employee performance, self-efficacy has a positive and significant effect on employee performance, and self-efficacy mediates the influence of transformational leadership on employee performance at the Samabe Hotel Bali Suite and Villas Nusa Dua, Badung.
\end{abstract}

Keywords: Transformational Leadership, Employee Performance, self-efficacy. 
Ida Bagus Agung Aditya Wijaya, Pengaruh Kepemimpinan Transformasional...

\section{PENDAHULUAN}

Berkembang pesatnya industri pariwisata di daerah Bali, menuntut penyediaan akomodasi hotel sebagai salah satu komponen penting. Perkembangan dunia usaha khususnya industri perhotelan di Bali, dewasa ini dirasakan semakin maju dan pesat yang membawa dampak persaingan yang semakin tajam.Dalam dunia yang diwarnai kompetisi global dengan persaingan yang semakin tinggi, khususnya dalam aspek bisnis dan ekonomi, perusahaan-perusahaan membutuhkan kinerja tinggi dari semua karyawannya. Pada saat yang sama, para karyawan membutuhkan umpan balik atas kinerja mereka sebagai pedoman bagi peningkatan perilaku kerja di masa yang akan datang (Marwansyah, 2015:228). Kinerja adalah tingkat keberhasilan di dalam melaksanakan tugas serta kemampuan untuk mencapai tujuan yang telah ditetapkan (Darodjat, 2015:113). Kinerja mencakup dua konsep efisiensi antara hubungan input dengan hasil, dan efektivitas yang menghubungkan kesesuaian hasil dengan pencapaian tujuan (Mahdinezhad, 2015).

Gaya kepemimpinan adalah salah satu faktor pentingyang mempengaruhikinerja karyawan. Menyangkut gaya kepemimpinan, maka dapat dikatakan gaya kepemimpinan modern yang penting adalah kepemimpinan transformasional (Yukl, 2014:290). Pemimpin yang memakai gaya kepemimpinan transformasional akan memotivasi bawahannya untuk menyelesaikan tugas dengan cara bawahannya masing-masing, jadi bawahan diajak untuk berpikir kreatif. Selain itu, bawahan akan diberikan tantangan yang terus meningkat kesulitannya (Bass et al, 2003). Gaya kepemimpinan ini banyak ditemukan dalam dunia bisnis saat ini karena dianggap lebih adaptif terhadap tantangan zaman dan lebih disukai oleh banyak orang. Oleh sebab itu gaya kepemimpinan dalam penelitian ini lebih ditekankan pada kepemimpinan transformasional.

Adanya pengaruh positif antara kepemimpinan transformasional terhadap kinerja karyawan ditunjukkan oleh hasil penelitian Setiawan (2015). Hasil konsisten ditunjukkan oleh penelitian Abasilim (2014) yang menemukan bahwa kepemimpinan transformasional memiliki pengaruh positif yang signifikan terhadap kinerja karyawan, dan karena itu direkomendasikan bahwa organisasi yang ingin meningkatkan atau menjamin kinerja organisasi yang optimal harus mengadopsi gaya kepemimpinan yang sesuai dan mampu berinteraksi dengan pengikutnya.

Efektifnya kepemimpinan transformasional ditentukan oleh tinggi rendahnya efikasi diri seorang karyawan yang merupakan keyakinan diri (sikap percaya diri) terhadap kemampuan sendiri untuk meningkatkan kinerja karyawan yang akan mengarahkannya kepada hasil yang diharapkan (Nurihsan, 2015:135). Menurut Baron \& Donn (2014:185) efikasi diri adalah keyakinan seseorang akan kemampuan atau kompetensinya atas kinerja tugas yang diberikan, mencapai tujuan atau mengatasi sebuah hambatan. Chan (2014) menyatakan efikasi diriadalah variabelmotivasiyangmempengaruhi individu terhadap kegiatan, pencapaiantujuan, ketekunandan kinerja dalamberbagai konteks. 
Hasil penelitian sebelumnya oleh Chan (2014) menemukan kepemimpinan transformasional berpengaruh signifikan terhadap efikasi diri dan efikasi diri berpengaruh signifikan terhadap kinerja karyawan. Temuan penelitian ini juga menunjukkan bahwa kepemimpinan transformasional berpengaruh signifikan terhadap kinerja karyawan dengan efikasi diri sebagai variabel mediasi. Penelitian lain oleh Harjono (2015) menunjukkan kepemimpinan transformasional dan efikasi diri berpengaruh positif dan signifikan terhadap kinerja karyawan. Hasil penelitian Jumari (2016) menunjukkan terdapat pengaruh yang positif dan signifikan efikasi diri terhadap kinerja. Kristiyana (2016) dalam penelitiannya menemukan efikasi diri mempunyai pengaruh yang signifikan terhadap kinerja pegawai, berarti kapabilitas atau keyakinan diri pegawai dalam menjalankan tugasnya memiliki pengaruh yang nyata terhadap kinerjanya.

Hotel Samabe Bali Suite and Villas Nusa Dua, Badung sebagai tempat penelitian, kegiatannya sebagian besar merupakan pelayanan kepada tamu (wisatawan), maka sudah selayaknya kinerja karyawan ditingkatkan berkaitan dengan proses administrasi dan kegiatan pelayanan kepada tamu (wisatawan). Mengetahui perkembangan usaha, adapun tingkat hunian kamar di Hotel Samabe Bali Suite and Villas Nusa Dua, Badung tahun 2014-2018terdapat pada Tabel 1.

Tabel 1.

Tingkat Hunian Kamar Di Hotel Samabe Bali Suite And Villas Nusa Dua, Badung Tahun 2014-2018

\begin{tabular}{ccccccc}
\hline Tahun & $\begin{array}{c}\text { Jumla } \\
\text { h Hari }\end{array}$ & $\begin{array}{c}\text { Jumla } \\
\mathbf{h} \\
\text { Kamar } \\
\text { (Unit) }\end{array}$ & $\begin{array}{c}\text { Jumlah } \\
\text { Kamar } \\
\text { Tersedia } \\
\text { (Unit) }\end{array}$ & $\begin{array}{c}\text { Jumlah } \\
\text { Kamar } \\
\text { Terjual } \\
\text { (Unit) }\end{array}$ & $\begin{array}{c}\text { Tingkat } \\
\text { Hunian } \\
\text { Kamar } \\
\mathbf{( \% )}\end{array}$ & $\begin{array}{c}\text { Perubaha } \\
\text { n Tingkat } \\
\text { Hunian } \\
\text { Kamar } \\
\text { (\%) }\end{array}$ \\
\hline 2014 & 366 & 81 & 29.646 & 18.452 & 62,24 & - \\
2015 & 365 & 81 & 29.565 & 19.654 & 66,48 & 6,81 \\
2016 & 365 & 81 & 29.565 & 20.922 & 70,77 & 6,45 \\
2017 & 365 & 81 & 29.565 & 19.740 & 66,77 & $(5,65)$ \\
2018 & 366 & 81 & 29.646 & 18.368 & 61,96 & $(7,20)$ \\
\hline
\end{tabular}

Sumber: Hotel Samabe Bali Suite and Villas Nusa Dua, Badung.

Berdasarkan Tabel 1. dapat dilihat bahwa tingkat hunian kamar di Hotel Samabe Bali Suite and Villas Nusa Dua, Badung dari tahun 2014 sampai tahun 2018 cenderung mengalami penurunan setiap tahunnya. Peningkatan hunian kamar terjadi pada tahun 2015sebesar 6,81 persen dan tahun 2016sebesar 6,45 persen, sedangkan penurunan terjadi dalam dua tahun terakhir yaitu pada tahun 2017 sebesar -5,65 persen dan tahun 2018 sebesar 7,20 persen. Tabel 2. juga menunjukkan tingkat hunian kamar dirasakan masih rendah, sehingga diperlukan usaha yang lebih keras dari manajemen untuk lebih meningkatkan kinerja karyawan sehingga tingkat hunian kamar juga dapat lebih ditingkatkan.

Masalah kinerja karyawan, juga dapat dilihat dari banyaknya guest complain wisatawan pada pelayanan yang diberikan. Lebih jelasnya dapat dilihat pada Tabel 2. 
Tabel 2.

Jumlah Guest Complain Wisatawan Pada Pelayanan Karyawan Di Hotel Samabe Bali Suite And Villas Nusa Dua, Badung Tahun 2014-2018

\begin{tabular}{|c|c|c|c|c|c|c|}
\hline \multirow[b]{2}{*}{ No } & \multirow[b]{2}{*}{ Pelayanan } & \multicolumn{5}{|c|}{$\begin{array}{c}\text { Jumlah Keluhan } \\
\text { (Orang) }\end{array}$} \\
\hline & & $\begin{array}{c}\text { Tahu } \\
\text { n } \\
2014 \\
\end{array}$ & $\begin{array}{c}\text { Tahu } \\
\text { n } \\
2015 \\
\end{array}$ & $\begin{array}{l}\text { Tahu } \\
\text { n } 216\end{array}$ & $\begin{array}{c}\text { Tahu } \\
\text { n } \\
2017 \\
\end{array}$ & $\begin{array}{c}\text { Tahu } \\
\text { n } \\
2018 \\
\end{array}$ \\
\hline 1 & $\begin{array}{l}\text { Kemampuan karyawan yang andal dalam } \\
\text { memberikan pelayanan kamar. }\end{array}$ & 8 & 11 & 12 & 8 & 10 \\
\hline 2 & $\begin{array}{l}\text { Cepat dan tanggap dalam memberikan } \\
\text { pelayanan. }\end{array}$ & 22 & 25 & 23 & 28 & 34 \\
\hline 3 & $\begin{array}{l}\text { Komunikasi yang baik antara karyawan dan } \\
\text { wisatawan. }\end{array}$ & 14 & 16 & 20 & 19 & 22 \\
\hline 4 & Jaminan keamanan bagi wisatawan. & 9 & 12 & 9 & 11 & 9 \\
\hline 5 & $\begin{array}{l}\text { Kemampuan karyawan receptionist } \\
\text { memberikan informasi yang dibutuhkan } \\
\text { wisatawan. }\end{array}$ & 6 & 9 & 11 & 12 & 14 \\
\hline 6 & Perhatian personal pada saat diperlukan. & 15 & 12 & 16 & 20 & 18 \\
\hline 7 & Penanganan keluhan wisatawan. & 14 & 13 & 15 & 21 & 25 \\
\hline & Jumlah & 88 & 98 & 106 & 119 & 132 \\
\hline
\end{tabular}

Sumber: Hotel Samabe Bali Suite and Villas Nusa Dua, Badung.

Berdasarkan Tabel 2. dapat disimak bahwa dari tahun 2014-2018, jumlah keluhan atau komplin wisatawan terhadap kinerja karyawan adalah selalu meningkat setiap tahunnya. Jumlah keluhan tertinggi terjadi pada tahun 2018 sebanyak 132 keluhan, dengan keluhan terbanyak adalah pada cepat dan tanggap dalam memberikan pelayanan jasa yaitu sebanyak 34 keluhan atau 25,76 persen. Hal ini menunjukkan adanya penurunan kinerja karyawan terutama berkaitan dengan dimensi kualitas pelayanan. Berdasarkan hasil wawancara pada beberapa orang karyawan, diketahui bahwa rendahnya kinerja karyawan ditunjukkan oleh kerja sama karyawan masih kurang dalam menyelesaikan pekerjaan sebagai sebuah tim disebabkan karena banyaknya beban kerja yang harus diselesaikan secara individual disertai tingginya persaingan antar sesama karyawan dan adanya ketidakcocokan bekerja sama dengan rekannya.

Terjadinya penurunan kinerja karyawan di Hotel Samabe Bali Suite and Villas Nusa Dua, Badung, maka perusahaan dituntut untuk senantiasa mengoptimalkan kinerja para karyawannya. Berbagai macam hambatan akan ditemui karyawan untuk dapat bekerja dengan baik, maka diperlukan kepemimpinan transformasional yang dimediasi dengan efikasi dirisehingga mampu mempengaruhi bawahan dalam mengarahkan dan menetapkan transformasi atau perubahan kinerja karyawan ke arah yang lebih baik, sehingga karyawan memiliki kepercayaan terhadap dirinya sendiri untuk dapat melakukan tugas sesuai kemampuan dan kompetensi yang dimilikinya.

Berdasarkan latar belakang masalah, maka sangat layak dalam penelitian ini diteliti lebih jauh lagi pengaruh kepemimpinan transformasional terhadap kinerja karyawan dengan efikasi dirisebagai variabel mediasi di Hotel Samabe Bali Suite and Villas Nusa Dua, Badung. 
Teori kognitif sosial berakar pada pandangan tentang human agency bahwa individu merupakan agen yang secara proaktif mengikutsertakan dalam lingkungan mereka sendiri dan dapat membuat sesuatu terjadi dengan tindakan mereka. Adapun kunci pengertian agency adalah kenyataan bahwa di antara faktor personal yang lain, individu memiliki self-beliefs yang memungkinkan mereka melatih mengontrol atas pikiran, perasaan, dan tindakan mereka, bahwa "apa yang dipikirkan, dipercaya, dan dirasakan orang mempengaruhi bagaimana mereka bertindak" (Mukhid, 2014).

Kinerja karyawan adalah suatu tindakan atau kegiatan yang ditampilkan oleh seseorang dalam melaksanakan aktivitas tertentu yang menjadi tugasnya (Darodjat, 2015:105).

Kepemimpinan transformasional adalah kepemimpinan yang mempunyai kekuatan untuk mempengaruhi bawahan dengan cara-cara tertentu. Dengan penerapan kepemimpinan transformasional bawahan akan merasa dipercaya, dihargai, loyal dan respek kepada pimpinannya. Pada akhirnya bawahan akan termotivasi untuk melakukan lebih dari yang diharapkan sehingga hasil yang dicapai lebih memuaskan (Yukl, 2014:224).

Menurut Bandura (1997) dalam Baron \& Donn (2014:183), efikasi diri adalah evaluasi seseorang terhadap kemampuan atau kompetensinya untuk melakukan sebuah tugas, mencapai tujuan atau mengatasi hambatan. Disebutkan juga efikasi diri adalah keyakinan seseorang akan kemampuan atau kompetensinya atas kinerja tugas yang diberikan, mencapai tujuan atau mengatasi sebuah hambatan.

Kerangka konseptual tentang pengaruh kepemimpinan transformasionalterhadap kinerja karyawan dengan efikasi diri sebagai variabel mediasi dapat digambarkan seperti pada Gambar 1.

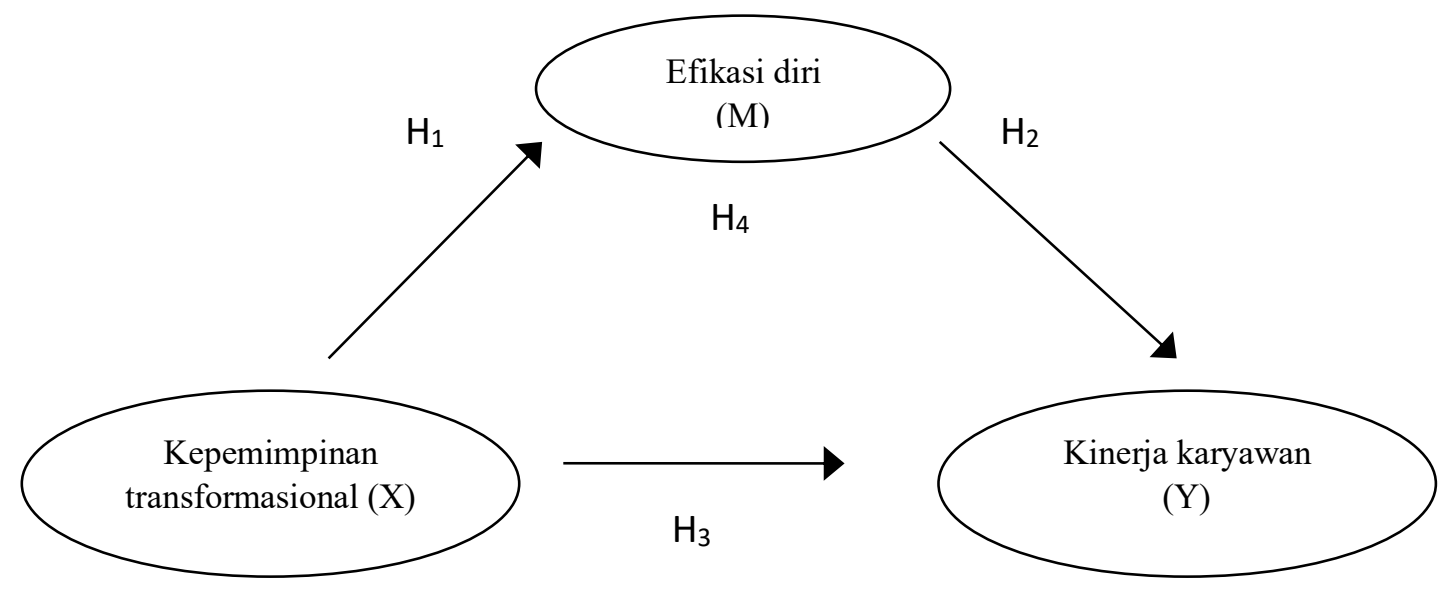

Gambar 1. Kerangka Konseptual

Sumber: Teori dan hasil penelitian sebelumnya.

Gambar 1. menunjukkan bahwa $\mathrm{H}_{1}$ adalah hipotesis yang menunjukkan pengaruh kepemimpinan transformasional terhadap efikasi diri. $\mathrm{H}_{2}$ adalah 
Ida Bagus Agung Aditya Wijaya, Pengaruh Kepemimpinan Transformasional...

hipotesis yang menjelaskan pengaruh efikasi diri terhadap kinerja karyawan. $\mathrm{H}_{3}$ adalah hipotesis yang menjelaskan pengaruh kepemimpinan transformasional terhadap kinerja karyawan. $\mathrm{H}_{4}$ adalah hipotesis yang menjelaskan peran efikasi diri memediasi pengaruh kepemimpinan transformasional terhadap kinerja karyawan.

Kepemimpinan transformasional menyerukan nilai-nilai moral dari pengikut dalam upayanya untuk meningkatkan kesadaran mereka tentang masalah etis dan untuk memobilisasi energi dan sumber daya mereka untuk mereformasi institusi. Lebih jelasnya kepemimpinan transformasional adalah kemampuan yang dimiliki oleh para pemimpin untuk mempengaruhi bawahannya untuk meningkatkan kesadaran tentang pentingnya kinerja (Yukl, 2014:292).

Pernyataan ini dipertegas secara empirik oleh beberapa hasil penelitian sebelumnya. Hasil penelitian Fitzgerald \& Schutte (2012) menemukan bahwa kepemimpinan transformasional berpengaruh positif dan signifikan terhadap kinerja karyawan dengan dimediasi oleh efikasi diri. Hasil penelitian Mesterova (2015) menunjukkan bahwa meningkatnya efikasi diri karyawan dapat ditingkatkan secara signifikan dengan pendekatan kepemimpinan transformasional. Beverborg (2015) dalam penelitiannya menemukan bahwa kepemimpinan transformasional yang memperhatikan dan memotivasi karyawan dalam proses kerja berkontribusi signifikan terhadap peningkatan efikasi diri karyawan. Mansouri \& Arani (2015) menemukan bahwa gaya kepemimpinan transformasional berdampak positif dan signifikan terhadap perubahan efikasi diri diri karyawan.

Berdasarkan temuan hasil penelitian maka dapat dijelaskan kepemimpinan transformasional yang efektif memiliki karakter mampu mengidentifikasi dirinya sebagai alat perubahan, berani, memercayai orang lain, motor penggerak nilai, pembelajar sepanjang masa, memiliki kemampuan untuk menghadapi kompleksitas dan ketidakpastian dan visioner. Jika kepemimpinan transformasional dilaksanakan dengan efektif maka akan memotivasi diri karyawan sehingga mempengaruhi kondisi psikologis seorang karyawan. Kondisi psikologis yang dimaksud dalam hal ini adalah keyakinan diri (efikasi diri) sebagai landasan kepribadian karyawan untuk bekerja lebih baik.

Berdasarkan telaah landasan teori dan kajian penelitian sebelumnya, maka dapat disusun hipotesis sebagai berikut:

$\mathrm{H}_{1}$ : Kepemimpinan transformasional berpengaruh positif dan signifikan terhadap efikasi diri

Kepemimpinan transformasional yang efektif akan mampu meyakinkan bawahan terhadap kemampuan mereka untuk melakukan tugas. Pimpinan mendelegasikan pekerjaan yang menantang kepada bawahan dan mengungkapkan harapan yang tinggi kepada bawahan dan dan meningkatkan efikasi diri karyawan tentang bagaimana mereka bekerja sehingga memenuhi harapannya (Aggarwal \& Krishnan, 2012).

Penelitian Repie (2014) berdasarkan hasil pengujian hipotesis menemukan bahwa gaya kepemimpinan transformasional berpengaruh positif terhadap kinerja karyawan. Hasil yang konsisten juga ditemukan pada beberapa penelitian lainnya. Vijaya (2014) dalam penelitian menemukan bahwa variabel gaya kepemimpinan 
transformasional memiliki pengaruh yang positif dan signifikan terhadap variabel kinerja karyawan. Kesimpulan dari penelitian Mondiani (2015) adalah kepemimpinan transformasional mempunyai pengaruh positif dan signifikan terhadap kinerja karyawan. Penelitian oleh Astuti (2014) menyimpulkan bahwa gaya kepemimpinan transformasional berpengaruh positif dan signifikan terhadap kinerja karyawan.

Berdasarkan temuan hasil penelitian maka dapat dijelaskan bahwa kepemimpinan transformasional menyerukan nilai-nilai moral dari pengikut dalam upayanya untuk meningkatkan kesadaran mereka tentang masalah etis dan untuk memobilisasi energi dan sumber daya mereka untuk mereformasi organisasi atau perusahaan. Lebih jelasnya kepemimpinan transformasional adalah kemampuan yang dimiliki oleh para pemimpin untuk mempengaruhi bawahannya untuk meningkatkan kesadaran tentang pentingnya kinerja karyawan, dimana karyawan memprioritaskan pentingnya kelompok, dan pimpinan meningkatkan kebutuhan bawahan mereka ke tingkat yang lebih tinggi untuk mencapai kualitas hidup yang lebih baik.

Berdasarkan telaah landasan teori dan kajian penelitian sebelumnya, maka dapat disusun hipotesis sebagai berikut:

$\mathrm{H}_{2}$ : Kepemimpinan transformasional berpengaruh positif dan signifikan terhadap kinerja karyawan

Efikasi diri menunjukkan kecenderungan seseorang melibatkan diri dalam kegiatan yang mengarah sasaran. Jika perilaku tersebut mengarah pada suatu obyek atau sasarannya maka dengan motivasi tersebut akan diperoleh pencapaian target atau sasaran yang sebesar-besarnya sehingga pelaksanaan tugas dapat dikerjakan dengan sebaik-baiknya, sehingga efektivitas kerja dapat dicapai dan kinerja juga akan meningkat (Fadzilah, 2015).

Pernyataan ini dipertegas secara empirik oleh beberapa hasil penelitian sebelumnya. Indrawati (2014) menemukan bahwa terdapat pengaruh yang positif dan signifikan dari efikasi diri terhadap kinerja perawat. Lunenburg (2014)dalam penelitiannya menemukan bahwa efikasi diri mempengaruhi kinerja karyawan secara signifikan dan juga mempengaruhi tingkat usaha dan ketekunan karyawan ketika mengerjakan tugas-tugas yang sulit. Penelitian Meier (2015) menemukan perubahan efikasi diri berpengaruh signifikan terhadap perubahan strategi manajerial dan kinerja organisasi. Hasil penelitian Sonali (2015) menunjukkan efikasi diri berhasil meningkatkan kinerja karyawan baik karyawan laki-laki maupun perempuan. Penelitian Iroegbu (2015) menemukan kognisi sosial teori Bandura tentang efikasi diri memiliki implikasi besar bagi dunia kerja dan kinerja karyawan dalam organisasi. Penelitian

Berdasarkan temuan hasil penelitian maka dapat dijelaskan bahwa efikasi diri merupakan keyakinan diri (sikap percaya diri) terhadap kemampuan sendiri untuk menampilkan tingkah laku yang akan mengarahkannya kepada hasil yang diharapkan. Faktor efikasi diri menentukan keberhasilan kinerja pada setiap perubahan organisasi, dengan kata lain bahwa kemampuan diri merupakan bagian yang sangat signifikan di dalam meningkatkan kinerja perusahaan.

Berdasarkan telaah landasan teori dan kajian penelitian sebelumnya, maka dapat disusun hipotesis sebagai berikut: 
$\mathrm{H}_{3}$ : Efikasi diri berpengaruh positif dan signifikan terhadap kinerja karyawan

Pada hampir semua perusahaan yang ada, karyawan merupakan salah satu aset yang mereka jaga dan kembangkan. Oleh karena itu, perusahaan dituntut untuk senantiasa mengoptimalkan kinerja para karyawannya. Berbagai macam hambatan akan ditemui karyawan untuk dapat bekerja dengan baik, maka diperlukan kepemimpinan transformasional yang dimediasi dengan efikasi diri sehingga mampu mempengaruhi bawahan dalam mengarahkan dan menetapkan transformasi (perubahan) kinerja karyawan ke arah yang lebih baik, sehingga karyawan memiliki kepercayaan terhadap dirinya sendiri untuk dapat melakukan tugas sesuai kemampuan dan kompetensi yang dimilikinya (Kilapong, 2014).

Pernyataan ini dipertegas dengan kajian empirik dari beberapa hasil penelirian sebelumnya. Hasil penelitian Cavazotte (2016) menunjukkan bahwa efikasi diri sebagai variabel mediasi memberikan efek positif dan signifikan bagi pengaruh kepemimpinan transformasional terhadap peningkatan kinerja karyawan. Barling (2015) dalam penelitiannya menemukan kepemimpinan transformasional tidak secara langsung berpengaruh terhadap kinerja yang lebih tinggi. Sebaliknya, tingkat efikasi diri yang lebih tinggi dari kepemimpinan transformasional akan memotivasi karyawan sehingga berpengaruh signifikan terhadap kinerja karyawan. Hasil penelitian Harjono (2015) menunjukkan kepemimpinan transformasional berpengaruh positif dan signifikan terhadap kinerja karyawan yang dimediasi oleh efikasi diri.

Berdasarkan temuan hasil penelitian maka dapat dijelaskan bahwa kepemimpinan transformasional menentukan tinggi rendahnya efikasi diri seorang karyawan yang merupakan keyakinan diri (sikap percaya diri) terhadap kemampuan sendiri untuk meningkatkan kinerja karyawan yang akan mengarahkannya kepada hasil yang diharapkan. Kepemimpinan transformasional yang dimediasi efikasi diri akan mampu memotivasi karyawan sehingga keyakinan karyawan akan kemampuan atau kompetensinya mampu meningkatkan kinerja tugas yang diberikan, atau dengan kata lain efikasi diri adalah variabel yang mempengaruhi kinerja.

Berdasarkan telaah landasan teori dan kajian penelitian sebelumnya, maka dapat disusun hipotesis sebagai berikut:

$\mathrm{H}_{4}$ : Efikasi diri berperan memediasi pengaruh kepemimpinan transformasional terhadap kinerja karyawan.

\section{METODE PENELITIAN}

Desain penelitian ini termasukdalam penelitian kuantitatif dengan pendekatan penelitian deskriptif dan analisis asosiatif, karena adanya variabelvariabel yang akan ditelaah hubungannya serta tujuannya untuk menyajikan gambaran mengenai hubungan antara variabel-variabel yang diteliti, yaitu untuk mengetahui peran efikasi diri memediasi pengaruh kepemimpinan transformasional terhadap kinerjakaryawan.

Penelitian ini dilakukan di Hotel Samabe Bali Suite and Villas beralamat di Jalan Pura Barong-Barong Sawangan, Nusa Dua, Badung. Adapun yang melatarbelakangi pemilihan lokasi pada penelitian ini adalah terjadinya penurunan 
kinerja karyawan yang terindikasi disebabkan oleh adanya permasalahan pada kepemimpinan transformasional dan efikasi diri. Obyek dalam penelitian adalah bidang manajemen sumber daya manusia yaitu kinerja karyawan, kepemimpinan transformasional dan efikasi diri

Berdasarkan pada pokok permasalahan yang telah dirumuskan serta hipotesis yang diajukan, maka variabel-variabel dalam penelitian ini dapat diidentifikasikan secara garis besar adalah sebagai berikut:

Tabel 3.

Indikator Variabel Penelitian

\begin{tabular}{lll}
\hline \multicolumn{1}{c}{ Variabel } & \multicolumn{1}{c}{ Indikator } & Sumber \\
\hline & 1. Kesetiaan & \\
Kinerja Karyawan (Y) & 2. Kualitas kerja & Harjono, \\
& 3. Kuantitas kerja & $(2015)$ \\
& 4. Kedisiplinan & \\
& 5. Kreativitas & \\
& 6. Kerjasama & Harjono, \\
& 1. Perilaku yang diidealkan & \\
Gaya kepemimpinan transformasional $\left(\mathrm{X}_{1}\right)$ & 2. Atribut yang diidealkan & \\
& 3. Pertimbangan individual & \\
& 4. Rangsangan intelektual & Harjono, \\
Efikasi diri( $\left.\mathrm{X}_{2}\right)$ & 5. Motivasi inspirasional & $(2015)$ \\
& 1. Past performance & \\
\hline Sumber: Data penelitian, 2020 & 2. Vicarious experience &
\end{tabular}

Populasi dalam penelitian ini adalah karyawan Hotel Samabe Bali Suite and Villas Nusa Dua, Badung tahun 2018 sebanyak 148 orang karyawan, tidak termasuk 1 orang General Manager sebagai pimpinan manajemen puncak (top management).

Sampel adalah sebagian dari populasi yang diambil sebagai sumber data dan dapat mewakili seluruh populasi. Berkaitan dengan penentuan sampel, apabila subjek kurang dari 100, maka lebih baik diambil semua, sehingga penelitiannya merupakan penelitian populasi. Selanjutnya jika subjeknya besar, dapat diambil antara 10-15 persen atau 20-25 persen atau lebih (Riduwan \& Akdon, 2015:253).

Metode penentuan sampel dalam penelitian ini menggunakan proportionate stratified random sampling, adalah pengambilan sampel sebesar 75 persen dari anggota populasi secara acak dan berstrata secara proporsional, dilakukan sampling iniapabila anggota populasinya heterogen (tidak sejenis) (Riduwan \& Akdon, 2015:254). Lebih jelasnya penentuan jumlah sampel penelitian yang dijadikan sebagai responden dapat dilihat pada Tabel 4.

Tabel 4. menjelaskan bahwa dengan menggunakan metode proportionate stratified random sampling dapat diketahui jumlah sampel penelitian sebagai responden adalah sebanyak 108 orang karyawan Hotel Samabe Bali Suite and Villas di Nusa Dua, Badung. 
Tabel 4.

Penentuan Jumlah Sampel Penelitian Di Hotel Samabe Bali Suite And VillasNusa Dua, Badung

\begin{tabular}{|c|c|c|c|c|}
\hline No & Bagian/Departemen & $\begin{array}{c}\text { Jumlah } \\
\text { Populasi } \\
\text { Karyawan } \\
\text { (Orang) } \\
\end{array}$ & $\begin{array}{c}\text { Jumlah } \\
\text { Sampel dari } \\
\text { Total Populasi } \\
(\mathbf{7 5 \%}) \\
\end{array}$ & $\begin{array}{l}\text { Jumlah } \\
\text { Sampel } \\
\text { (Orang) }\end{array}$ \\
\hline \multirow[t]{3}{*}{1} & Top Management & & & \\
\hline & a. General Manager Secretary & 1 & 0,75 & 1 \\
\hline & b. Assistant General Manager & 1 & 0,75 & 1 \\
\hline 2 & Front Office Department & 13 & 9,75 & 10 \\
\hline 3 & Housekeeping Department & 63 & 47,25 & 47 \\
\hline 4 & Sales and Marketing Department & 8 & 6,00 & 6 \\
\hline 5 & Security Department & 16 & 12,00 & 12 \\
\hline 6 & Food and Beverage Department & 16 & 12,00 & 12 \\
\hline 7 & $\begin{array}{l}\text { Human Resources Development (HRD) } \\
\text { Department }\end{array}$ & 7 & 5,25 & 5 \\
\hline 8 & Engineering Department & 7 & 5,25 & 5 \\
\hline 9 & Accounting Department & 12 & 9,00 & 9 \\
\hline \multicolumn{2}{|c|}{ Jumlah } & 144 & - & 108 \\
\hline
\end{tabular}

Sumber: Hotel Samabe Bali Suite and Villas di Nusa Dua, Badung

Pengujian hipotesis untuk mengetahui pengaruh langsung menggunakan analisis jalur (path analysis). Terdapat dua set regresi yang dibentuk, yaitu:

(1) Persamaan struktural 1 adalah: $M=\beta 1 X+$ e 1

(2) Persamaan struktural 2 adalah: $Y=\beta 2 X+\beta 3 \mathrm{M}+\mathrm{e} 2$.

\section{HASIL DAN PEMBAHASAN}

Samabe Bali Suite and Villas merupakan salah satu hotel yang ada di Nusa Dua, Badung. Hotel ini didirikan pada tahun 2009 oleh Ibu Lindratini selaku owner dan dikelola oleh PT Samudera Mahkota Beach di atas tanah seluas 8 hektar dengan alamat di Jalan Pura Barong-Barong Sawangan, Nusa Dua, Badung. Hotel ini terletak pada lokasi yang strategis, hanya dua puluh menit berkendaraan dari bandara serta akses langsung menuju private beach. Samabe Bali Suite and Villas mempunyai bangunan arsitektur nuansa Bali dengan view pantai berpasir putih dengan taman-taman tropis disekitar hotel, dengan jumlah kamar sebanyak 81 unit terdiri dari 39 unit suite dan 42 unit villa. Semua kategori jenis kamar berhadapan langsung dengan samudra hindia. Hal tersebut merupakan nilai jual yang tinggi, terutama bagi para wisatawan yang ingin berlibur ke Bali.

Legalitas usaha Samabe Bali Suite and Villas terdiri dari (1) Surat Ijin Usaha Bupati Badung No.556.8/020/Diparda, tanggal 15 Agustus 2009 dan Surat Ijin Usaha ini wajib didaftar ulang di Kantor Dinas Pariwisata Kabupaten Badung setiap lima tahun sekali, terakhir adalah pada tanggal 15 Agustus 2014, (2) Surat Izin Mendirikan Bangunan Nomor 546 Tahun 2009 yang dikeluarkan oleh Bupati Badung dan Kepala Dinas Citra Karya Kabupaten Badung, (3) Surat Tanda Daftar Ulang Ijin Tempat Usaha dan Ijin Undang Undang Gangguan (Hider Ordonnantie) Nomor 521.21/904/EK, tangal 29 Nopember 2009 yang dikeluarkan oleh Bupati dan Sekertaris Daerah Badung. Tanda Daftar Ulang ini 
berlaku selama 5 (lima) tahun, (4) Tanda Daftar Perusahaan berbentuk Perseroan Terbatas dengan Nomor 220855503002, tanggal 8 September 2014 yang dikeluarkan oleh Kepala Dinas Perindustrian dan Perdagangan Kabupaten Badung. Surat Ini berlaku sampai dengan empat tahun.

Investasi yang diperlukan untuk pendirian hotel ini berasal dari modal yang disetor oleh pemilik dan untuk pengembangan selanjutnya modal berasal dari laba hasil operasi perusahaan. Sampai saat ini, ekspansi yang telah dilakukan semua sumber dananya berasal dari laba hasil operasional perusahaan.

Karakteristik responden yang terdapat dalam penelitian ini dapat dibedakan berdasarkan dari umur, jenis kelamin, pendidikan terakhir dan departemen. Gambaran karakteristik responden di Samabe Bali Suite and Villas dapat dilihat pada Tabel 5 .

Tabel 5.

Karakteristik Responden Di Samabe Bali Suite and Villas Nusa Dua, Badung

\begin{tabular}{|c|c|c|c|c|}
\hline \multirow[b]{2}{*}{ No } & \multirow[b]{2}{*}{ Karakteristik } & \multirow[b]{2}{*}{ Keterangan } & \multicolumn{2}{|c|}{ Jumlah } \\
\hline & & & $\begin{array}{c}n \\
\text { (Orang) }\end{array}$ & $\begin{array}{c}\% \\
\text { (Persen) } \\
\end{array}$ \\
\hline \multirow[t]{5}{*}{1} & Umur & 21-30 tahun & 31 & 28,70 \\
\hline & & 31-40 tahun & 45 & 41,67 \\
\hline & & 41-50 tahun & 21 & 19,44 \\
\hline & & $>50$ tahun & 11 & 10,19 \\
\hline & Jumlah & & 108 & 100,00 \\
\hline \multirow[t]{3}{*}{2} & Jenis kelamin & Laki-laki & 84 & 77,78 \\
\hline & & Perempuan & 24 & 22,22 \\
\hline & Jumlah & & 108 & 100,00 \\
\hline \multirow[t]{4}{*}{3} & Pendidikan terakhir & SMA & 37 & 34,26 \\
\hline & & Diploma & 56 & 51,85 \\
\hline & & $\mathrm{S} 1$ & 15 & 13,89 \\
\hline & Jumlah & & 108 & 100,00 \\
\hline \multirow[t]{10}{*}{4} & Departemen & Top Management & 2 & 1,85 \\
\hline & & Front Office Department & 10 & 9,26 \\
\hline & & Housekeeping Department & 47 & 43,52 \\
\hline & & Sales and Marketing Department & 6 & 5,56 \\
\hline & & Security Department & 12 & 11,11 \\
\hline & & Food and Beverage Department & 12 & 11,11 \\
\hline & & $\begin{array}{l}\text { Human Resources Development } \\
\text { (HRD) Department }\end{array}$ & 5 & 4,63 \\
\hline & & Engineering Department & 5 & 4,63 \\
\hline & & Accounting Department & 9 & 8,33 \\
\hline & Jumlah & & 108 & 100,00 \\
\hline
\end{tabular}

Sumber: Data penelitian, 2018.

Berdasarkan Tabel 5. maka dapat dilihat bahwa berdasarkan umur responden yang terbanyak berada pada rentang umur 31-40 tahun yaitu 32 orang atau 51,61 persen dari seluruh sampel, selanjutnya adalah umur 21-30 tahun sebanyak 31 orang atau 28,70 persen, umur 41-50 tahun adalah 21 orang atau 19,44 persen dan yang paling sedikit berqada pada rentang umur lebih dari 50 tahun yaitu 11 orang atau 10,19 persen. Berdasarkan jenis kelamin, jumlah responden laki-laki adalah sebanyak 84 orang atau 77,78 persen atau tiga kali lipat lebih banyak dari karyawan perempuan yaitu sebanyak 24 orang atau 22,22 
persen. Pendidikan terakhir responden,sebagian besar adalah lulusan diplomayaitu 56 orang atau 51,85 persen, selanjutnya SMA sebanyak 37 orang atau 34,26 persen dan S1 sebanyak 15 orang atau 13,89 persen. Jumlah responden berdasarkan departemen sesuai dengan struktur organisasi, yang terbanyak adalah pada Housekeeping Departmentyaitu 47 orang atau 43,52 persen.

Pengujian instrumen penelitian menggunakan uji validitas dan reliabilitas dengan bantuan program SPSS 20.0 for windows, setelah skor jawaban responden yang berupa data ordinal diubah menjadi data interval, dengan hasil sebagai berikut.

Pengujian validitas masing-masing instrumen penelitian yang diperoleh dari jawaban kuesioner sangat penting dilakukan untuk memperoleh hasil penelitian yang valid. Suatu instrumen dikatakan valid atau sah apabila memiliki koefisien korelasi antara item dengan skor total lebih besar dari 0,30. Hasil uji validitas instrumen penelitian, dapat dilihat pada Tabel 6.

Tabel 6.

Hasil Uji Validitas Instrumen Penelitian

\begin{tabular}{|c|c|c|c|c|c|}
\hline \multirow[b]{2}{*}{ No } & \multirow[b]{2}{*}{ Variabel } & \multirow[b]{2}{*}{$\begin{array}{c}\text { Item } \\
\text { Pernyataan }\end{array}$} & \multicolumn{3}{|c|}{ Validitas dan Reliabilitas } \\
\hline & & & $\begin{array}{l}\text { Koefisien } \\
\text { Korelasi } \\
\end{array}$ & $\begin{array}{c}\text { Cronbach's } \\
\text { Alpha }\end{array}$ & Keterangan \\
\hline \multirow[t]{6}{*}{1} & Kinerja karyawan & $\mathrm{Y}_{1.1}$ & 0,906 & 0,915 & Valid dan \\
\hline & $(\mathrm{Y})$ & $\mathrm{Y}_{1.2}$ & 0,858 & & Reliabel \\
\hline & & $\mathrm{Y}_{1.3}$ & 0,877 & & \\
\hline & & $\mathrm{Y}_{1.4}$ & 0,833 & & \\
\hline & & $\mathrm{Y}_{1.5}$ & 0,743 & & \\
\hline & & $\mathrm{Y}_{1.6}$ & 0,815 & & \\
\hline \multirow[t]{5}{*}{2} & Kepemimpinan & $\mathrm{X}_{1.1}$ & 0,832 & 0,839 & Valid dan \\
\hline & transformasional $(\mathrm{X})$ & $\mathrm{X}_{1.2}$ & 0,727 & & Reliabel \\
\hline & & $\mathrm{X}_{1.3}$ & 0,769 & & \\
\hline & & $\mathrm{X}_{1.4}$ & 0,816 & & \\
\hline & & $\mathrm{X}_{1.5}$ & 0,758 & & \\
\hline \multirow[t]{4}{*}{3} & Efikasi diri(M) & $\mathbf{M}_{1.1}$ & 0,825 & 0,860 & Valid dan \\
\hline & & $\mathrm{M}_{1.2}$ & 0,857 & & Reliabel \\
\hline & & $\mathrm{M}_{1.3}$ & 0,844 & & \\
\hline & & $\mathbf{M}_{1.4}$ & 0,830 & & \\
\hline
\end{tabular}

Sumber: Data penelitian, 2018.

Tabel 6. menunjukkan bahwa instrumen penelitian variabel kinerja karyawan, kepemimpinan transformasional dan efikasi diri seluruhnya adalah valid. Koefisien korelasi product moment seluruh instrumen penelitian adalah lebih besar dari 0,30 dan memiliki nilai koefisien Cronbach's alphalebih besar dari 0,60 sehingga dikatakan validdan reliabel, hal ini berarti instrumen penelitian adalah sah yaitu pernyataan-pernyataan pada kuesioner mampu mengungkapkan apa yang diukur oleh kuesioner tersebut dan dapat digunakan dalam analisis.

Berdasarkan hasil olahan data dengan curve fit hasil pengujian asumsi linearitas dapat diringkas ke Tabel 7. 
Tabel 7.

Hubungan Linier Antar Variabel

\begin{tabular}{cccccc}
\hline Equation & $\boldsymbol{R}$ Square & $\boldsymbol{F}$ & $\boldsymbol{d f 1}$ & $\boldsymbol{d f 2}$ & Sig. \\
\hline $\mathrm{X} \rightarrow \mathrm{M}$ & 0,735 & 294,166 & 1 & 106 & 0,000 \\
$\mathrm{X} \rightarrow \mathrm{Y}$ & 0,605 & 162,066 & 1 & 106 & 0,000 \\
$\mathrm{M} \rightarrow \mathrm{Y}$ & 0,700 & 247,378 & 1 & 106 & 0,000 \\
\hline
\end{tabular}

Sumber: Data penelitian, 2018.

Berdasarkan Tabel 7. dapat diketahui bahwa hubungan kepemimpinan transformasional $(\mathrm{X}) \rightarrow$ efikasi diri $(\mathrm{M})$ dengan nilai signifikansi sebesar $0,000<$ $\alpha=0,050$.Hubungan kepemimpinan transformasional $(\mathrm{X}) \rightarrow$ kinerja karyawan (Y) dengan nilai signifikansi sebesar $0,000<\alpha=0,050$.Hubungan efikasi diri (M) $\rightarrow$ kinerja karyawan (Y) dengan nilai signifikansi sebesar $0,000<\alpha=0,050$. Hasil ini menunjukkan hubungan antar variabel adalah linier, karena memiliki nilai signifikansi lebih kecil dari 5 persen $(\alpha=0,050)$.

Berdasarkan hasil olahan data dua set regresi maka dapat diringkas seperti pada Tabel 8.

Tabel 8.

Pengaruh Langsung Variabel Penelitian

\begin{tabular}{ccccccc}
\hline \multirow{2}{*}{$\begin{array}{c}\text { Hubungan } \\
\text { variabel }\end{array}$} & $\begin{array}{c}\text { Unstandardized } \\
\text { Coefficients }\end{array}$ & $\begin{array}{c}\text { Standardized } \\
\text { Coefficients }\end{array}$ & SE & $\boldsymbol{t}$ & Sig. & $\boldsymbol{R}^{\mathbf{2}}$ \\
\hline $\mathrm{X} \rightarrow \mathrm{M}$ & 0,731 & 0,857 & 0,043 & 17,151 & 0,000 & 0,735 \\
$\mathrm{X} \rightarrow \mathrm{Y}$ & 0,294 & 0,227 & 0,131 & 2,239 & 0,027 & 0,714 \\
$\mathrm{M} \rightarrow \mathrm{Y}$ & 0,976 & 0,642 & 0,154 & 6,327 & 0,000 & 0,714 \\
\hline
\end{tabular}

Sumber: Data penelitian, 2018.

Berdasarkan Tabel 8. maka dapat dirumuskanpersamaan struktural 1 sebagai berikut: $\mathrm{M}=\beta 1 \mathrm{X}+\mathrm{e} 1$

Perhitungan nilai error term (e1):

$$
\begin{aligned}
& \text { e1 }=\sqrt{1-0,735} \\
& \text { e1 }=\sqrt{0,265}=0,515
\end{aligned}
$$

Berdasarkan nilai koefisien regresi standar dan error term maka diperoleh persamaan struktural 1 adalah:

$$
\begin{aligned}
& M=\beta 1 X+e 1 \ldots \ldots \ldots \ldots \\
& M=0,857 X+0,515 .
\end{aligned}
$$

Persamaan struktural 2 adalah: $Y=\beta 2 X+\beta 3 \mathrm{M}+\mathrm{e} 2$

Perhitungan nilai error term (e2):

$$
\begin{aligned}
& \text { e1 }=\sqrt{1-0,714} \\
& \text { e1 }=\sqrt{0,286}=0,535
\end{aligned}
$$

Berdasarkan nilai koefisien regresi standar dan error term maka diperoleh persamaan struktural 2 adalah:

$$
\begin{aligned}
& \mathrm{Y}=\beta 2 \mathrm{X}+\beta 3 \mathrm{M}+\mathrm{e} 2 \ldots \ldots \ldots \ldots \ldots \ldots \\
& \mathrm{Y}=0,227 \mathrm{X}+0,642 \mathrm{M}+0,535
\end{aligned}
$$

Berdasarkan nilai e1 dan e2 maka dapat dihitung koefisien determinasi total sebagai berikut: 


$$
\begin{aligned}
\mathrm{R}^{2}=1-(\mathrm{e} 1)^{2}(\mathrm{e} 2)^{2} & =1-(0,515)^{2}(0,535)^{2} \\
& =1-0,076=\quad 0,924
\end{aligned}
$$

Koefisien determinasi total sebesar 0,924 mempunyai arti bahwa sebesar 92,40 persen variasi kinerja karyawan dipengaruhi oleh variasi kepemimpinan transformasional dan efikasi diri, sedangkan sisanya sebesar 7,60 persen dijelaskan oleh faktor lain diluar model.

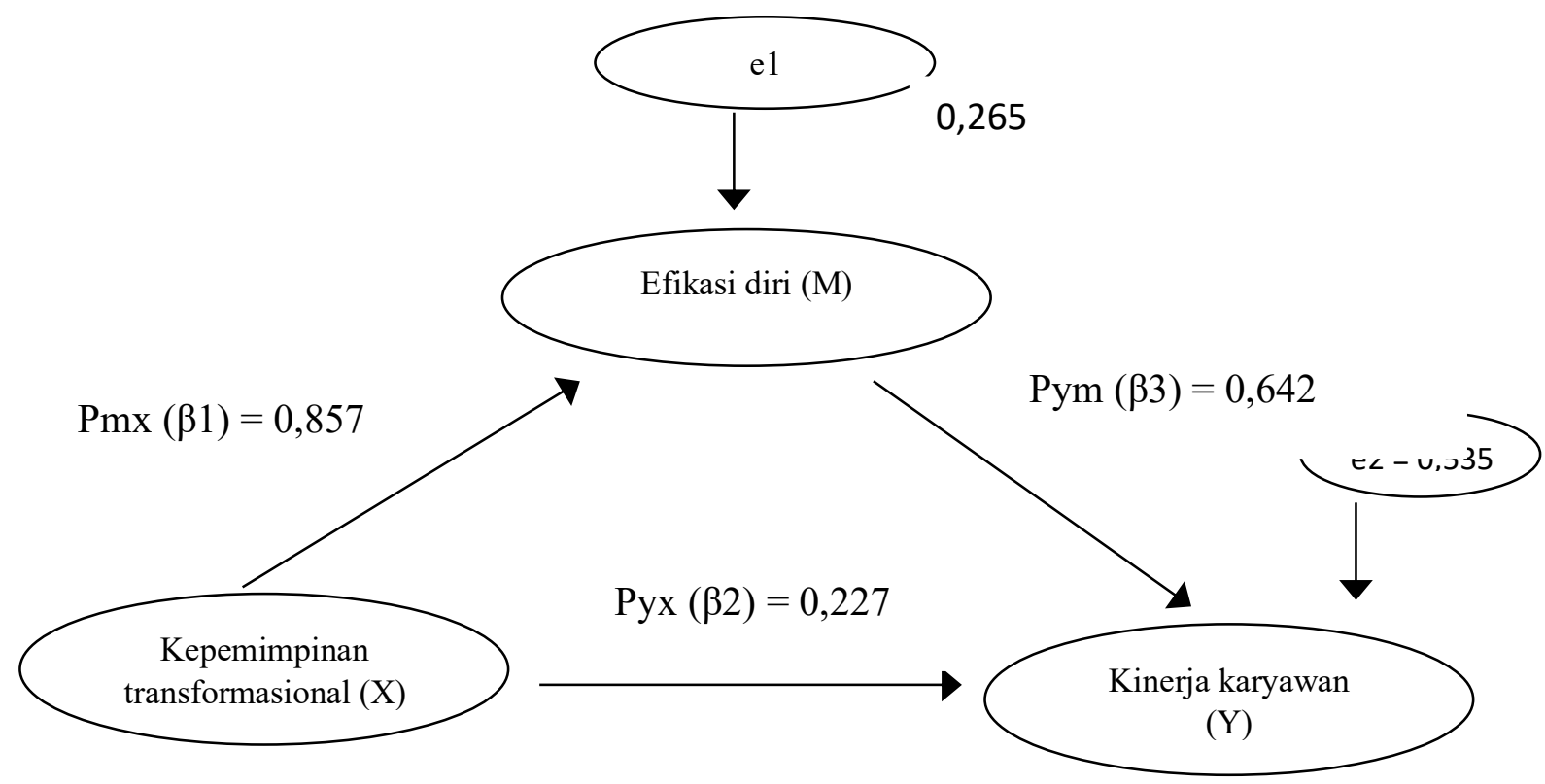

\section{Gambar 2. Diagram Jalur Pengaruh Kepemimpinan TransformasionalTerhadap Kinerja Karyawan Melalui Efikasi Diri}

Sumber: Hasil analisis, 2018.

Berdasarkan Gambar 2. dapat dilihat bahwa variabel kinerja karyawan lebih besar dipengaruhi oleh efikasi diri dengan koefisien jalur sebesar 0,642, sedangkan pengaruh kepemimpinan transformasional terhadap kinerja karyawan hanya 0,227 dan pengaruh kepemimpinan transformasional terhadap efikasi diriadalah 0,857 .

Pengujian pengaruh tidak langsung dilakukan dengan Perhitungan statistikberikut :

$$
\begin{aligned}
& \mathrm{S}_{\mathrm{ab}}=\sqrt{0,976^{2} \cdot 0,043^{2}+0,731^{2} \cdot 0,154^{2}} \\
& \mathrm{~S}_{\mathrm{ab}}=\sqrt{0,95258 \cdot 0,00185+0,53436-0,02372} \\
& \mathrm{~S}_{\mathrm{ab}}=\sqrt{0,00176+0,01268} \\
& \mathrm{~S}_{\mathrm{ab}}=\sqrt{0,01444}=0,12017 \\
& \mathrm{z}=\frac{\mathrm{ab}}{\mathrm{S}_{\mathrm{ab}}}=\frac{0,731 \cdot 0,976}{0,12017}
\end{aligned}
$$




$$
z=\frac{0,71346}{0,12017}=5,93709=5,937
$$

Oleh karena z hitung sebesar 5,937 adalah lebih kecil dari 1,96 berarti efikasi diri berperan mediasi pengaruh kepemimpinan transformasional terhadap kinerja karyawan.

Hasil analisis jalur menunjukkan bahwa kepemimpinan transformasional dapat berpengaruh langsung ke kinerja karyawan dan dapat juga berpengaruh tidak langsung yaitu dari kepemimpinan transformasional ke efikasi diri (sebagai variabel atau intervening) lalu ke kinerja karyawan.

Besarnya pengaruh langsung (Pyx)

Pengaruh tidak langsungnya $(\operatorname{Pmx} \times \mathrm{Pym}=0,857 \times 0,642)$

Pengaruh total

$$
\begin{aligned}
& =0,227 \\
& =0,551 \\
& =0,778
\end{aligned}
$$

Jadi pengaruh langsung kepemimpinan transformasional terhadap kinerja karyawan adalah sebesar 0,227, pengaruh tidak langsung kepemimpinan transformasional terhadap kinerja karyawan melalui efikasi diri adalah sebesar 0,551, dan efikasi diri memediasi pengaruh kepemimpinan transformasional terhadap kinerja karyawan adalah sebesar 0,778 .

Berdasarkan Tabel 8. menunjukkan nilai $\mathrm{t}=17,151$ dengan nilai probabilitas (signifikansi) $=0,000<\alpha=0,050$ maka $\mathrm{H}_{0}$ ditolak dan $\mathrm{H}_{1}$ diterima. Jadi kepemimpinan transformasionalberpengaruh secara positif dan signifikan terhadap efikasi diri, artinya kepemimpinan transformasionaldapat meningkatkan efikasi diri, sehingga semakin tinggi kepemimpinan transformasional maka semakin tinggi pula efikasi diri. Hasil ini mendukung penelitian sebelumnya oleh Fitzgerald \& Schutte (2012) yang menemukan bahwa kepemimpinan transformasional positif dan signifikan terhadap kinerja karyawan. Mansouri \& Arani (2015) menemukan bahwa gaya kepemimpinantransformasional berdampak positif dan signifikan terhadap perubahan efikasi diri dirikaryawan. Hasil penelitian Mesterova (2015) menunjukkan bahwa meningkatnya efikasi diri karyawan dilakukan dengan pendekatan kepemimpinan transformasional. Beverborg (2015) dalam penelitiannya menemukan bahwa kepemimpinan transformasional yang memperhatikan danmemotivasi karyawan dalam proses kerja berkontribusi signifikan terhadap peningkatan efikasi diri karyawan. Hasil penelitian juga mempertegas pernyataan teori. Kepemimpinan transformasional menyerukan nilai-nilai moral dari pengikut dalam upayanya untuk meningkatkan kesadaran mereka tentang masalah etis dan untuk memobilisasi energi dan sumber daya mereka untuk mereformasi institusi. Lebih jelasnya kepemimpinan transformasional adalah kemampuan yang dimiliki oleh para pemimpin untuk mempengaruhi bawahannya untuk meningkatkan kesadaran tentang pentingnya kinerja (Yukl, 2014:292).

Berdasarkan Tabel 8. menunjukkan nilai $\mathrm{t}=2,239$ dengan nilai probabilitas (signifikansi) $=0,027<\alpha=0,050$ maka $\mathrm{H}_{0}$ ditolak dan $\mathrm{H}_{2}$ diterima. Jadi kepemimpinan transformasional berpengaruh secara positif dan signifikan terhadap kinerja karyawan. Artinya apabila kepemimpinan transformasionalmaka akan diikuti oleh meningkatnya kinerja karyawan. Hasil ini mendukung penelitian sebelumnya oleh penelitian Repie (2014) yang membuktikan bahwa gaya 
Ida Bagus Agung Aditya Wijaya, Pengaruh Kepemimpinan Transformasional...

kepemimpinan transformasional berpengaruh positif terhadap kinerja karyawan. Vijaya (2014) dalam penelitian menemukan bahwa variabel gaya kepemimpinan transformasional memiliki pengaruh yang positif dan signifikan terhadap variabel kinerja karyawan. Kesimpulan dari penelitian Mondiani (2015) adalah ada pengaruh positif dan signifikan kepemimpinan transformasional terhadap kinerja karyawan. Penelitian oleh Astuti (2014) menyimpulkan bahwa gaya kepemimpinan transformasional berpengaruh positif dan signifikan terhadap kinerja karyawan.Hasil penelitian juga mempertegas pernyataan teori. Kepemimpinan transformasionalyang efektif akan mampu meyakinkan bawahan terhadap kemampuan mereka untuk melakukan tugas. Pimpinan mendelegasikan pekerjaan yang menantang kepada bawahan dan mengungkapkan harapan yang tinggi kepada bawahan dan dan meningkatkan efikasi dirikaryawan tentang bagaimana mereka bekerja sehingga memenuhi harapannya (Aggarwal \& Krishnan, 2012).

Berdasarkan Tabel 8. menunjukkan nilai $\mathrm{t}=6,327$ dengan nilai probabilitas (signifikansi) $=0,000<\alpha=0,050$ maka $\mathrm{H}_{0}$ ditolak dan $\mathrm{H}_{3}$ diterima. Jadi efikasi diri berpengaruh secara positif dan signifikan terhadap kinerja karyawan. Artinya semakin tinggi efikasi diri maka semakin tinggi kinerja karyawan. Hasil ini mendukung penelitian sebelumnya oleh Indrawati (2014) yang membuktikan bahwa terdapat pengaruh yang positif dan signifikan dari efikasi diri terhadap kinerja perawat. Lunenburg (2014) dalam penelitiannya menemukan bahwa efikasi dirimempengaruhi kinerja karyawan secara signifikan dan juga mempengaruhi tingkat usaha dan ketekunan karyawan ketika mengerjakan tugas-tugas yang sulit. Penelitian Meier (2015) menemukan perubahan efikasi diriberpengaruh signifikan terhadap perubahan strategi manajerial dan kinerja organisasi. Hasil penelitian Sonali (2015) menunjukkan efikasi diri berhasil meningkatkan kinerja karyawan baik karyawan laki-laki maupun perempuan. Penelitian Iroegbu (2015) menemukan kognisi sosial teori Bandura tentang efikasi diri memiliki implikasi besar bagi dunia kerja dan kinerja karyawan dalam organisasi. Hasil penelitian juga mempertegas pernyataan teori. Efikasi diri menunjukkan kecenderungan seseorang melibatkan diri dalam kegiatan yang mengarah sasaran. Jika perilaku tersebut mengarah pada suatu obyek atau sasarannya maka dengan motivasi tersebut akan diperoleh pencapaian target atau sasaran yang sebesar-besarnya sehingga pelaksanaan tugas dapat dikerjakan dengan sebaik-baiknya, sehingga efektivitas kerja dapat dicapai dan kinerja juga akan meningkat (Fadzilah, 2015).

Hasil penelitian menunjukkan efikasi diri berperan memediasi secara positif dan signifikan pengaruh kepemimpinan transformasional terhadap kinerja karyawan di Hotel Samabe Bali Suite and Villas Nusa Dua, Badung. Artinya meningkatnya kepemimpinan transformasional akan meningkatkan kinerja karyawan apabila dimediasi hubungannya oleh efikasi diri. Hasil ini mendukung penelitian sebelumnya oleh Cavazotte (2016) menunjukkan bahwa efikasi dirisebagai variabel mediasi memberikan efek positif dan signifikan bagi pengaruh kepemimpinan transformasional terhadap peningkatan kinerja karyawan. Barling (2015) dalam penelitiannya menemukan kepemimpinan transformasional tidak secara langsung berpengaruh terhadap kinerja yang lebih 
tinggi. Sebaliknya, tingkat efikasi diriyang lebih tinggi dari kepemimpinan transformasional akan memotivasi karyawan sehingga berpengaruh signifikan terhadap kinerja karyawan. Hasil penelitian Harjono (2015) menunjukkan kepemimpinan transformasional berpengaruh positif dan signifikan terhadap kinerja karyawan yang dimediasi oleh efikasi diri.

Hasil penelitian juga mempertegas pernyataan teori. Pada hampir semua perusahaan yang ada, karyawan merupakan salah satu aset yang mereka jaga dan kembangkan. Oleh karena itu, perusahaan dituntut untuk senantiasa mengoptimalkan kinerja para karyawannya. Berbagai macam hambatan akan ditemui karyawan untuk dapat bekerja dengan baik, maka diperlukan kepemimpinan transformasional yang dimediasi dengan efikasi dirisehingga mampu mempengaruhi bawahan dalam mengarahkan dan menetapkan transformasi (perubahan) kinerja karyawan ke arah yang lebih baik.Karyawan memiliki kepercayaan terhadap dirinya sendiri untuk dapat melakukan tugas sesuai kemampuan dan kompetensi yang dimilikinya (Kilapong, 2014).

Penelitian ini dapat memberikan informasi penting bagi Hotel Samabe Bali Suite and Villas Nusa Dua, Badung agar dapat meningkatkan kepemimpinan transformasional di lingkungan perusahaan yang dapat dirasakan oleh karyawannya sehingga dapat meningkatkan efikasi diri karyawan. Efikasi dirimerupakan keyakinan diri (sikap percaya diri) terhadap kemampuan sendiri untuk menampilkan tingkah laku yang akan mengarahkannya kepada hasil yang diharapkan.Faktor efikasi diri menentukan keberhasilan kinerja pada setiap perubahan organisasi, dengan kata lain bahwa kemampuan diri merupakan bagian yang sangat signifikan di dalam meningkatkan kinerja perusahaan. Kepemimpinan transformasional yang dimediasi efikasi diri akan mampu memotivasi karyawan sehingga keyakinan karyawan akan kemampuan atau kompetensinya mampu meningkatkan kinerja tugas yang diberikan, atau dengan kata lain efikasi diriadalah variabelyangmempengaruhi kinerja.Penelitian ini juga diharapkan dapat memberikan sumbangan terhadap ilmu pengetahuan khususnnya manajemen sumber daya manusia, sekaligus memperkaya teori-teori kepemimpinan transformasional, efikasi diri dan kinerja karyawan.

\section{SIMPULAN}

Berdasarkan hasil analisis penelitian maka dapat disimpulkan Kepemimpinan transformasional berpengaruh positif dan signifikan terhadap efikasi diridi Hotel Samabe Bali Suite and Villas Nusa Dua, Badung, Kepemimpinan transformasional berpengaruh positif dan signifikan terhadap kinerja karyawan di Hotel Samabe Bali Suite and Villas Nusa Dua, Badung. Efikasi diri berpengaruh positif dan signifikan terhadap kinerja karyawan di Hotel Samabe Bali Suite and Villas Nusa Dua, Badung. Efikasi diri berperan mediasi pengaruh kepemimpinan transformasional terhadap kinerja karyawan di Hotel Samabe Bali Suite and Villas Nusa Dua, Badung

Berdasarkan hasil analisis penelitian, hasil pembahasan serta kesimpulan, maka saran yang dapat diberikan yaitu Kinerja karyawan ditingkatkan dengan cara meningkatkan potensi karyawan sehingga mampu melahirkan ide-ide baru 
atau kreatif dalam pekerjaan melalui pelaksanaan diklat secara berkala. Kepemimpinan transformasional sebaiknya lebih ditingkatkan dengan cara pimpinan lebih sering mengakui dan menghargai kinerja karyawan secara terbuka, caranya adalah dengan memberikan pujian dan memberikan penghargaan atas prestasi kerja karyawan dalam bentuk finansial. Meningkatkan efikasi diri dilakukan dengan cara menempatkan karyawan pada tiap departemen atau jabatan sesuai dengan kemampuan karyawan.

\section{REFERENSI}

Abasilim, D. U. (2014). Transformational Leadership Style and Its Relationship with Organisational Performance in Nigerian Work Context: A Review. Journal of Business and Management, 16(9), 1-5.

Aggarwal, J., \& Krishnan, V. R. (2012). Impact of Transformational Leadership on Follower' s Self-efficacy: Moderating Role of Follower' s Impression Management. Journal of Great Lakes Institute of Management Chennai, 12(4), 1-17.

Barling, J. (2015). Transformational Leadership Elevating Employees to Affect The Bottom Line. Journal of Queen Executive Development Centre, 4(2), 14.

Baron, R., \& Donn, B. (2014). Psikologi Sosial (Alih Bahasa: Ratna Djuwita). Jakarta: Erlangga.

Bass, B. M., Avolio, B. J., Jung, D. I., \& Berson, Y. (2003). Predicting Unit Performance by Assessing Transformational and Transactional Leadership. Journal of Applied Psychology, 88(2), 207-218.

Beverborg, A. O. G. (2015). Towards Sustaining Levels of Reflective Learning: How Do Transformational Leadership, Task Interdependence, and Selfefficacy Shape Teacher Learning in Schools? Journal of Societies, 5(2), 187219.

Cavazotte, F. (2016). Transformational Leaders and Work Performance: The Mediating Roles of Identification and Self-efficacy. Journal BAR Rio de Janeiro, 10(4), 490-512.

Chan, S. C. H. (2014). The Psychological Mechanisms of Transformational Leadership to Followers' Performance. Journal Department of Management and Marketing, The Hong Kong Polytechnic University, 6(1), 1-18.

Darodjat, T. A. (2015). Konsep-Konsep Dasar Manajemen Personalia Masa Kini. Bandung: PT Refika Aditama.

Fadzilah, A. (2015). Analisis Pengaruh Pemberdayaan Karyawan dan Self of Efficacy Terhadap Kinerja Karyawan Bagian Penjualan (Studi Kasus pada PT Sinar Sosro Wilayah Pemasaran Semarang). Jurnal Studi Manajemen Dan Organisasi, 3(1), 12-27.

Fitzgerald, S., \& Schutte, N. S. (2012). Increasing Transformational Leadership 
Through Enhancing Self-efficacy. Journal of Management Development, $29(5), 495-505$.

Harjono, G. J. (2015). Pengaruh Kepemimpinan Transformasional dan Selfefficacy Terhadap Kinerja Pegawai PT Air Manado. Jurnal EMBA, 3(3), 1040-1049.

Hasibuan, M. S. P. (2014). Manajemen Sumber Daya Manusia. Jakarta: PT Bumi Aksara.

Indrawati, Y. (2014). Pengaruh Self Esteem, Self-efficacy Dan Kepuasan Kerja Terhadap Kinerja Karyawan (Studi Kasus Perawat RS Siloam Manado). Jurnal Riset Bisnis Dan Manajemen, 2(4), 12-24.

Iroegbu, M. N. (2015). Self-efficacy and Work Performance: A Theoretical Framework of Albert Bandura's Model, Review of Findings, Implications and Directions for Future Research. Psychology and Behavioral Sciences, 4(4), 170-173.

Jumari. (2016). Pengaruh Budaya Organisasi, Efikasi Diri dan Kepuasan Kerja Terhadap Kinerja Mengajar Guru Smk Negeri Kecamatan Denpasar Selatan. E-Journal Program Pascasarjana Universitas Pendidikan Ganesha, 4(1), 113.

Kilapong, S. N. (2014). Kepemimpinan Transformasional, Self-efficacy, Self Esteem Pengaruhnya Terhadap Kepuasan Kerja Karyawan PT Tropica Cocoprima Manado. Jurnal EMBA, 1(4), 141-150.

Kristiyana, N. (2016). Kontribusi Self-efficacy Dalam Upaya Meningkatkan Kinerja Perbankan pada Bank XY di Ponorogo. Jurnal Fakultas Ekonomi Universitas Muhamadiyah Ponorogo, 2(5), 1-17.

Lunenburg, F. C. (2014). Self-efficacy in the Workplace: Implications for Motivation and Performance. International Journal of Management, Business, and Administration, 14(1), 1-6.

Mahdinezhad, M. (2015). Transformational, Transactional Leadership Styles and Job Performance of Academic Leaders. International Education Studies, 6(11), 29-34.

Marwansyah. (2015). Manajemen Sumber Daya Manusia. Bandung: Alfabeta.

Meier, K. J. (2015). Isopraxis Leadership: Self-efficacy, Managerial Strategy, and Organizational Performance. Department of Political Science Texas A and M University, 3(1), 1-40.

Mensah, A. O. (2015). The Influence of Employees' Self-efficacy on Their Quality of Work Life: The Case of Cape Coast, Ghana. International Journal of Business and Social Science, 4(2), 195-205.

Mesterova, J. (2015). Relationship between Self-efficacy, Transformational Leadership and Leader Effectiveness. Journal of Advanced Management Science, 3(2), 109-122. 
Ida Bagus Agung Aditya Wijaya, Pengaruh Kepemimpinan Transformasional...

Nam Sung, H. (2015). The Relationship among Self-efficacy, Social Influence, Performance Expectancy, Effort Expectancy, and Behavioral Intention in Mobile Learning Service. International Journal of Science and Technology, 8(9), 197-206.

Nia, S. F. (2014). Pengaruh Kepuasan Kerja, Self-efficacy, Locus of Control Terhadap Kinerja Karyawan (Study Empiris pada PT Batam Textile Industry Ungaran). Jurnal Program Studi Akuntansi Fakultas Ekonomi Dan Bisnis Universitas Muhammadiyah Surakarta, 2(3), 1-12.

Riyadiningsih, H. (2015). Peran Kondisi Psikologis dan Karakteristik Pribadi Dalam Pengembangan Kepemimpinan Efektif: Sebuah Tinjauan Konseptual. Jurnal Program Studi Manajemen Unwiku, 4(1), 1-8.

Setiaji. (2015). Pengaruh Kepemimpinan Transformasional, Kemampuan Diri dan Kepuasan Kerja Terhadap Kinerja Pegawai Dinas Pendidikan Kabupaten Klaten Derajat. Jurnal Program Studi Magister Manajemen Program Pasca Sarjana Universitas Muhammadiyah Surakarta, 3(4), 1-14.

Setiawan, D. (2015). Pengaruh Gaya Kepemimpinan Transformasional dan Transaksional Terhadap Kepuasan Kerja dan Kinerja Karyawan di PT Tohitindo Multi Craft Industries Krian. Jurnal Fakultas Ilmu Administrasi Universitas Brawijaya Malang, 6(2), 1-11.

Shah, M., and Arani, M. S. (2015). The Effect of Transformational Leadership on Employees' Self-efficacy. International Research Journal of Applied and Basic Sciences, 9(8), 1328-1339.

Yukl, G. A. (2014). Kepemimpinan Dalam Organisasi. Jakarta: Indeks. 